\title{
Detection of yellow-head virus (YHV) of Penaeus monodon by RT-PCR amplification
}

\author{
Chainarong Wongteerasupaya ${ }^{1}$, Wansika Tongchuea ${ }^{2}$, Vichai Boonsaeng ${ }^{3, *}$, \\ Sakol Panyim ${ }^{3}$, Anchalee Tassanakajon ${ }^{4}$, Boonsirm Withyachumnarnkul ${ }^{5}$, T. W. Flegel ${ }^{6}$ \\ 'Dept Biochemistry, Faculty of Medicine, Srinakharinwirot University, Soi 23 Sukhumvit Road, Bangkok 10110, Thailand \\ ${ }^{2}$ National Center for Genetic Engineering and Biotechnology, Rama 6 Road, Bangkok 10400, Thailand \\ ${ }^{3}$ Dept Biochemistry, ${ }^{5}$ Dept Anatomy and ${ }^{6}$ Dept Biotechnology, Faculty of Science, Mahidol University, Rama 6 Road, \\ Bangkok 10400, Thailand \\ ${ }^{4}$ Dept Biochemistry, Faculty of Science, Chulalongkorn University, Phya Thai Road, Bangkok 10400, Thailand
}

\begin{abstract}
A nucleic acid probe was developed using CDNA prepared from ssRNA extracted from yellow-head virus (YHV), a serious pathogen of the black tiger prawn Penaeus monodon. The specificity and sensitivity of this probe was established using dot-blot hybridization with nucleic acid extracts from YHV and from shrimp, bacteria and other viruses. Based on the sequence of this cloned YHV cDNA fragment, a YHV specific primer set for reverse transcription polymerase chain reaction (RT-PCR) of a 135 base pair (bp) sub-fragment was designed for detection of YHV infections in penaeid shrimp. When applied in RT-PCR with templates derived from experimentally or naturally YHV-infected shrimp and with purified YHV or YHV nucleic acid, the expected $135 \mathrm{bp}$ amplification product was obtained. By contrast, nucleic acids extracted from tissue samples of healthy shrimp and from other shrimp pathogens gave no such fragment. This confirmed the specificity of the designed YHV RNA specific primers. RTPCR based detection demonstrated high sensitivity, in that it could detect $0.01 \mathrm{pg}$ of purified YHV-RNA. In a time course study of an experimental YHV infection, the RT-PCR detection showed evidence of infection at 6 to $12 \mathrm{~h}$ post exposure to the virus. However, histopathology typical of YHV infection [i.e. karyorhexis and pycnosis of haemocytes in haematoxylin and eosin (H\&E) stained haemolymph smears] was not visible until 42 to $48 \mathrm{~h}$ post exposure. The results suggested that RT-PCR might be useful to shrimp aquaculturists for early detection of YHV outbreaks or for detection of asymptomatic carriers.
\end{abstract}

KEY WORDS: Yellow-head virus (YHV) P Polymerase chain reaction (PCR) Penaeus monodon

\section{INTRODUCTION}

Yellow-head virus (YHV) of the black tiger prawn Penaeus monodon was first discovered in Thailand in 1992, although it is now known to have caused extensive losses on the eastern coast of the Gulf of Thailand as early as 1991 (Flegel et al. 1995). Shrimp infected with YHV often show light yellow coloration of the dorsal cephalothorax area and have a pale or bleached appearance (Limsuwan 1991\}. Upon initial discovery, the virus was considered to be a granulosis-like virus (Boonyaratpalin et al. 1993, Chantanachookhin et al.

·Addressee for correspondence. E-mail: scvbs@mahidol.ac.th
1993), but later work showed that it was actually an RNA virus (Wongteerasupaya et al. 1995a). Two viruses which morphologically resemble YHV have also been reported in lymphoid organs (Spann et al. 1995) and gills (Spann et al. 1998) of Penaeus monodon from Australia. The virus from Thailand is also known to infect other species of penaeid shrimp in laboratory tests (Lu et al. 1994, 1997, Lightner 1996, Flegel et al. 1997), so it is not a potential pathogen solely to $P$. monodon. Since YHV is an RNA virus, cDNA preparation was necessary in order to characterize its nucleic acid and to prepare a diagnostic probe. The final aim was to develop a rapid, simple and sensitive reverse transcription polymerase chain reaction (RT-PCR) based system that would allow early detection of the virus. 


\section{MATERIALS AND METHODS}

Viral isolation and nucleic acid extraction. YHV was isolated from experimentally infected juvenile shrimp Penaeus monodon as described by Wongteerasupaya et al. (1995b). The YHV RNA was extracted from purified virions using guanidinium thiocyanate and was purified by $\mathrm{CsCl}$ gradient ultracentrifugation as described by Wongteerasupaya et al. (1995a).

RNA extraction by Trizol' ${ }^{\mathrm{M}}$ reagent. To prepare total RNA extracts for use as RT-PCR templates, $50 \mathrm{mg}$ of shrimp gill tissue or $50 \mu \mathrm{l}$ of haemolymph was treated with Trizol $^{\text {rM }}$ reagent for extraction of RNA (Bethesda Research Laboratories, Gaithersberg, MD, USA), following the instructions in the reagent manual.

Preparation of double-stranded cDNA. Using RNA extracted from purified YHV as a template, cDNA was prepared at $37^{\circ} \mathrm{C}$ for $50 \mathrm{~min}$, in $20 \mu \mathrm{l}$ of reaction mixture containing $2.5 \mu \mathrm{M}$ random hexamer (Sigma), $50 \mathrm{U}$ Maloney murine leukemia virus reverse transcriptase (M-MLV) (Bethesda Research Laboratories, Gaithersberg, MD), 20 U of RNase inhibitor (Bethesda Research Laboratories, Gaithersberg, MD), $1 \mathrm{mM}$ each deoxyribonucleotide triphosphate (dNTP), $5 \mathrm{mM} \mathrm{MgCl}_{2}$, $50 \mathrm{mM} \mathrm{KCl}, 10 \mathrm{mM}$ Tris- $\mathrm{HCl}(\mathrm{pH} 8.3)$. Using 2 to $5 \mathrm{ml}$ of this, double-stranded cDNA was synthesized in a final volume of $50 \mu$ l reaction mixture containing a final concentration of $2 \mathrm{mM} \mathrm{MgCl}_{2}, 0.1 \mathrm{mM}$ each dNTP, $50 \mathrm{mM} \mathrm{KCl}, 10 \mathrm{mM}$ Tris- $\mathrm{HCl}$ (pH 8.3) and $2.5 \mu \mathrm{M}$ random hexamer. The sample was subjected to amplification in a DNA thermal cycler (Perkin Elmer Cetus) at $95^{\circ} \mathrm{C}, 30 \mathrm{si} 20^{\circ} \mathrm{C}, 5 \mathrm{~min}$; and $37^{\circ} \mathrm{C}, 2 \mathrm{~min}$, for 8 cycles with the addition of $1 \mu \mathrm{l}$ of $5 \mathrm{U} \mathrm{\mu l}^{-1}$ of Klenow fragment enzyme (Boehringer Mannheim Genius System) at each annealing step.

Cloning and screening of cDNA clones. The cDNA was digested with Sau3AI and the resulting fragments were ligated to BamHI digested Bluescribe plasmid (Stratagene) and transformed into Escherichia coli JM107. Transformants were selected on Luria-Bertaniagar containing $50 \mu \mathrm{g} \mathrm{m} \mathrm{m}^{-1}$ ampicillin, $1 \mathrm{mM}$ IsopropylD-thiogalacto-pyranoside (Sigma) and 2\% 5-bromo-4chloro-3-indoyl-galactoside (Sigma). Selected cDNA clones were then used as probes in dot-blot hybridizations with YHV RNA and nucleic acid preparations from various other sources. These included 1000, 100, and 10 ng of YHV RNA, shrimp genomic DNA, whitespot baculovirus DNA (WSBV) and control transcribed RNA from plasmid PAW109 (Perkin Elmer Cetus). Clones which gave positive hybridization only with YHV RNA were selected for further study.

DNA sequence and primer designation. The sequence of 1 selected YHV clone which gave good specificity for YHV-RNA was determined by the dideoxy chain termination method using Sequence kit version 2.0 (USB) and ( $\alpha$-35S) dATP (Amersham) with $\mathrm{M} 13 / \mathrm{mp} 18$ oligonucleotides as the sequencing primer. Then nucleotide primers were designed by using the programme Oligo version 4.0.

Amplification of a YHV-specific fragment by reverse transcription polymerase chain reaction. Extracted YHV RNA was incubated at $42^{\circ} \mathrm{C}$ for $15 \mathrm{~min}$ to synthesize cDNA in $20 \mu \mathrm{l}$ of PCR buffer $(10 \mathrm{mM}$ Tris $-\mathrm{HCl}$, $\mathrm{pH} 8.3,50 \mathrm{mM} \mathrm{KCl}$ ) containing $2.5 \mathrm{U}$ of $\mathrm{M}$-MLV reverse transcriptase, $1.0 \mathrm{U}$ of ribonuclease inhibitor, $0.75 \mathrm{mM}$ of antisense primer (144R), $1 \mathrm{mM}$ each of dATP, dTTP, dCTP, and dGTP, and $5 \mathrm{mM}$ of $\mathrm{MgCl}_{2}$. Following cDNA synthesis, the mixture was incubated at $100^{\circ} \mathrm{C}$ for $5 \mathrm{~min}$ to inactivate the reverse transcriptase and then the product was allowed to cool to $5^{\circ} \mathrm{C}$. The PCR mixture (10 mM Tris- $\mathrm{HCl}, \mathrm{pH} 8.3,50 \mathrm{mM} \mathrm{KCl}$ ) containing $2.5 \mathrm{U}$ of Taq DNA polymerase (Perkin Elmer Cetus), $2 \mathrm{mM}$ $M \mathrm{MCl}_{2}$ and 0.75 mivi of sense primer ( $\left.10 F\right)$ was added to the reverse transcription product, giving a final volume of $100 \mu \mathrm{l}$. The tubes were overlaid with $100 \mu \mathrm{l}$ of mineral oil. PCR amplification was carried out for 40 cycles at $94^{\circ} \mathrm{C}, 30 \mathrm{~s} ; 58^{\circ} \mathrm{C}, 30 \mathrm{~s}$; and $72^{\circ} \mathrm{C}, 30 \mathrm{~s}$ and finishing at $72^{\circ} \mathrm{C}$ for $10 \mathrm{~min}$. In every set of experiments, a negative control was included. This contained diethylpyrocarbonate (DEPC)-treated distilled water instead of RNA. Amplified products were detected by electrophoresis of $20 \mu \mathrm{l}$ aliquots through $2 \%$ agarose gels in Tris-BorateEDTA (TBE) buffer.

Specificity of RT-PCR detection. Nucleic acid preparations including Penaeus monodon DNA, white-spot baculovirus WSBV DNA (Wongteerasupaya et al. 1995b), hepatopancreatic parvovirus (HPV) DNA (DiagXotics Co. Ltd, Wheaton, CT, USA), nuclear polyhedrosis virus (NPV) DNA (obtained from Rice Research Center, Kasetsart University, Thailand), Salmonella DNA and control plasmid PAW109 DNA (Perkin Elmer Cetus) were used as negative control templates for RTPCR. From each RT-PCR reaction $20 \mu \mathrm{l}$ was analysed by ethidium bromide stained gel electrophoresis.

Sensitivity of RT-PCR detection. Various amounts of YHV genomic RNA from $1 \mathrm{ng}$ to $0.01 \mathrm{fg}$ were used as templates in RT-PCR. Then $20 \mu l$ of each RT-PCR reaction mixture was analysed by ethidium bromidestained gel electrophoresis.

Time course detection of YHV in experimental infection. Twenty-seven juvenile shrimp of $20 \mathrm{~g}$ average weight were infected with $0.1 \mathrm{ml}$ of a thawed gill extract from experimentally YHV-infected shrimp (Wongteerasyupaya et al. 1995b). Fresh haemolymph (50 $\mu 1)$ was then collected from 3 of these infected shrimp every $6 \mathrm{~h}$ and immediately mixed with $500 \mu \mathrm{l}$ of Trizol ${ }^{\mathrm{TM}}$ reagent to be subsequently extracted by the procedure described above. The resuspended RNA $(2 \mu l)$ was then subjected to RT-PCR. Then $20 \mu l$ of each RT-PCR reaction was analysed by ethidium bromide- 
stained gel electrophoresis. Haemolymph $(0.1 \mathrm{mi})$ was also drawn from the sampled shrimp into an equal volume of $25 \%$ formalin and mixed thoroughly before making smears on microscope slides for staining with haematoxylin and eosin (H\&E). Finally, the specimens were fixed in Davidson's fixative after haemolymph removal. Gills fragments from these fixed specimens were stained as whole fragments with H\&E for microscopic examination as whole mounts (Flegel et al. 1995).

Southern blot hybridization. Southern blot hybridizations were carried out using digoxigenin-labeled DNA (Boehringer Mannheim Genius System) according to the Boehringer manual.

\section{RESULTS}

\section{Dot-blot selection of pMUY412 probe}

A total of 45 transformed, white clones were obtained on selective medium. Randomly, 12 clones were digoxigenin labelled and tested by dot blot hybridization. Clone pMUY412 [containing a 412 base pair (bp) insert of viral cDNA] was selected because it gave strongest positive hybridization with YHV genomic RNA but gave negative hybridization with healthy shrimp DNA, WSBV DNA and control transcribed RNA from plasmid PAW109.

\section{Sequence analysis and primer design}

The nucleotide sequence of the 412 bp cDNA fragment was analyzed and a set of PCR primers (10F of $21 \mathrm{bp}$ and $144 \mathrm{R}$ of $20 \mathrm{bp}$ ) was designed to amplify a $135 \mathrm{bp}$ fragment of YHV genomic RNA. The sequence of the $135 \mathrm{bp}$ fragment (Fig. 1) gave no significant homology with the DNA sequence or putative protein sequences in existing international databases (i.e. Genbank, EMBL and SWISS PROTEIN databases).

\section{Specificity of RT-PCR for YHV detection}

In specificity tests of the YHV RT-PCR assay for YHV using $10 \mathrm{~F}$ and $144 \mathrm{R}$ primers, 2 other economically important Thai shrimp pathogens (WSBV and HPV) and other nucleic acid templates (NPV, Salmonella, Penadeus monodon and plasmid PAW 109 DNA) gave no amplification product. The primers were shown to be specific for the selected region of the YHV genome (Fig. 2). A negative RT-PCR result was also obtained with $10 \mathrm{ng}$ and $1 \mathrm{ng}$ of purified YHV-RNA when the reverse transcription reaction step was omitted (Fig. 2; lanes 9 and 10 ).

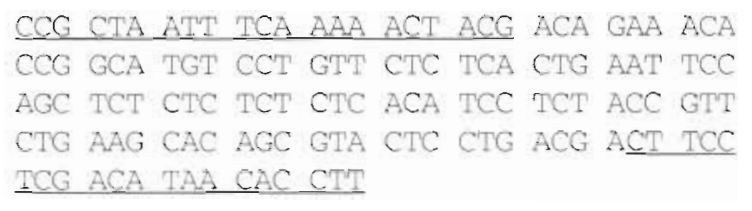

Fig. 1. The sequence of the 135 bp YHV fragment in pMUY412. The underlined portion represents the position of the amplification primers $10 \mathrm{~F}$ and $144 \mathrm{R}$

\section{Sensitivity of detection}

To evaluate the sensitivity of the YHV RT-PCR assay, the reverse transcription and subsequent amplification reactions were carried out using purified viral genomic RNA. Various amounts of YHVRNA were prepared by serial dilution in the range of $1 \mathrm{ng}$ to $0.01 \mathrm{fg}$ and subjected to RT-PCR for 40 cycles of amplification. When $20 \mu \mathrm{l}$ of RT-PCR product from a $100 \mu$ l total reaction volume was directly analysed, the result showed that an amplification product could be visualized by ethidium bromide staining when as little as $0.01 \mathrm{pg}$ of YHV-RNA was used as the template (Fig. 3A). Moreover, the sensitivity could be increased about 100 times when detection was by Southern blot hybridization using the digoxigenin-dUTP labeled pMUY412 parent fragment as a probe (Fig. 3B).

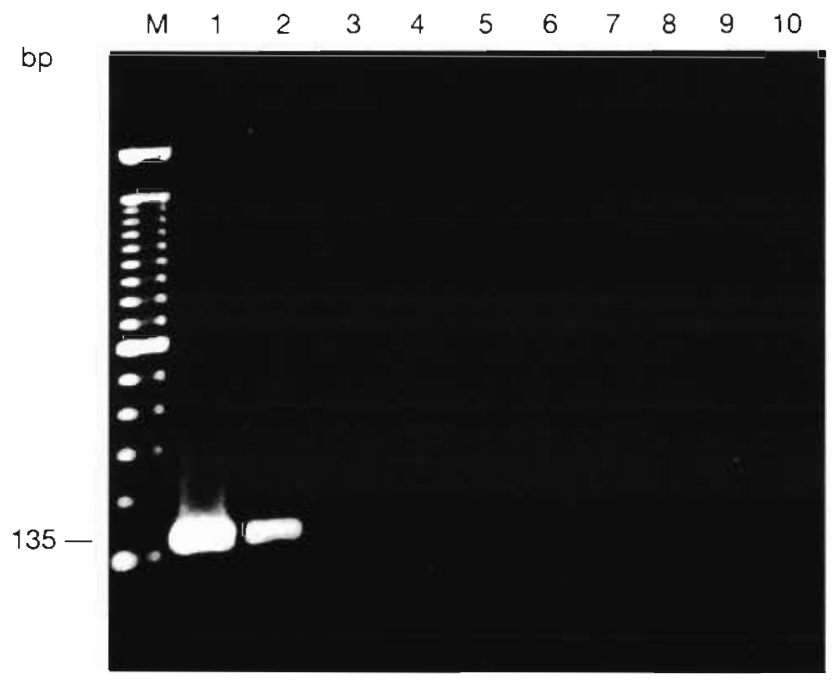

Fig. 2. Ethidium bromide staining of RT-PCR products amplified at an annealing temperature of $52^{\circ} \mathrm{C}$ for 40 cycles using 10 and $1 \mathrm{ng}$ of YHV RNA (lanes 1 and 2), WSBV DNA (lane 3), HPV DNA (lane 4), NPV DNA (lane 5), Salmonella DNA (lane 6), healthy shrimp DNA (lane 7) and control template RNA from plasmid PAW109 (lane 8). No RT-PCR product was obtained for $10 \mathrm{ng}$ and $1 \mathrm{ng}$ of purified YHV RNA when the reaction omitted the step of reverse transcription (lanes 9 and 10). Lane $M$ contained a 100 bp ladder marker 


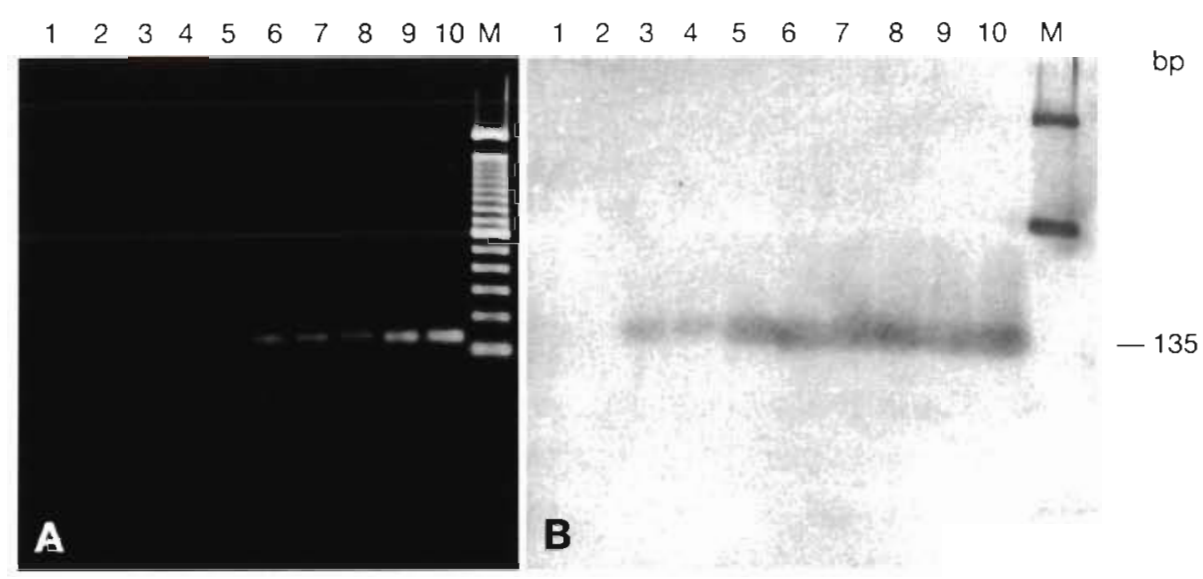

Fig. 3. Sensitivity of the RT-PCR assay. (A) Ethidium bromide staining of RT-PCR products amplified at an annealing temperature of $52^{\circ} \mathrm{C}$ for 40 cycles using serially diluted $(1: 10)$ YHV genomic RNA in the range of $1 \mathrm{ng}$ to $0.01 \mathrm{fg}$ as the template for RT-PCR (lanes 10 to 2, respectively). RT-PCR product at $20 \mu$ from a total reaction volume of $100 \mu l$ was directly analysed. The gel in (A) was transferted by Southern viot for hybridization with Dig-dUTP labeled pMUY412 probe (B) No RT-PCR product was obtained using $10 \mathrm{ng}$ of healthy shrimp DNA as the template (lane 1). Lane M contained a $100 \mathrm{bp}$ size marker

\section{Time course RT-PCR detection of YHV in laboratory shrimp infections}

RT-PCR was carried out on haemolymph samples at various times after injection of YHV extracts into shrimp in the laboratory. At times $0,6,12$, and $18 \mathrm{~h}$ post injection (p.i.), haemolymph was collected and RNA was extracted by Trizol ${ }^{\mathrm{TM}}$ reagent. The extract was subjected to RT-PCR using the optimized procedure described above. The results showed that RT-PCR could detect YHV very early during infection. It was found that 2 of 3 tested shrimp gave low to moderate RT-PCR products at $6 \mathrm{~h}$ p.i. At 12 and $18 \mathrm{~h}$ p.i., all 3 tested shrimp gave moderate to strong RT-PCR product bands. No RT-PCR product was obtained at time $0 \mathrm{~h}$ or with normal shrimp DNA (Fig. 4). The stability of haemolymph samples was low. Fresh or Trizol-fixed haemolymph from YHV-infected shrimp gave positive RT-PCR reactions if stored for not more than $12 \mathrm{~h}$ at $-80^{\circ} \mathrm{C}$. Longer periods of storage at $-80^{\circ} \mathrm{C}$ resulted in negative $\mathrm{RT}$ $P C R$ reactions.

The ability of RT-PCR to detect YHV in experimentally infected shrimp was compared to detection by H\&E staining. The results demonstrated that RT-PCR was much more sensitive, in that YHV could be detected in all 3 of the YHV-injected shrimp by $12 \mathrm{~h}$ p.i. (Table 1). By contrast, H\&E staining of haemolymph samples and gills revealed typical YHV histopathology only at $48 \mathrm{~h} \mathrm{p.i.}$

For a preliminary field test, haemolymph samples $(10 \mu \mathrm{l})$ were collected from 5 shrimp randomly selected from each of 6 ponds near to a pond diagnosed as infected with YHV. The haemolymph samples from each pond were pooled (total $50 \mu \mathrm{l}$ ) and then extracted with Trizol $^{\mathrm{TM}}$ reagent. The extracts were then subjected to RT-PCR using the optimized conditions described. Of the 6 ponds tested, 2 were YHV positive by RT-PCR amplification and 4 were not. Within 1 mo after sampling, all of the shrimp in 1 positive pond were lost to YHV. All the other shrimp crops were lost to $\mathrm{YHV}$ in the subsequent month.

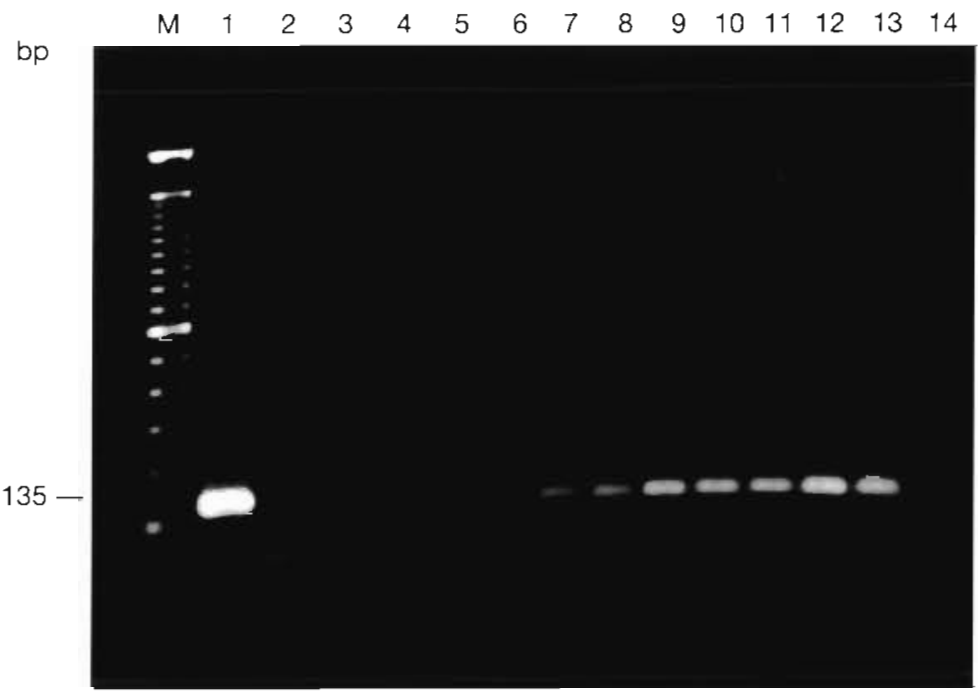

Fig. 4. RT-PCR products at various times post injection of YHV into shrimp. Ethidium bromide staining of RT-PCR products amplified at an annealing temperature of $52^{\circ} \mathrm{C}$ for 40 cycles using $10 \mathrm{ng}$ of YHV RNA (lane 1). RT-PCR products of 3 experimentally infected shrimp at $0 \mathrm{~h}$ (lanes 2 to 4), $6 \mathrm{~h}$ (lanes 5 to 7), $12 \mathrm{~h}$ (lanes 8 to 10) and $18 \mathrm{~h}$ (lanes 11 to 13) post injection. No RT-PCR product was obtained using $10 \mathrm{ng}$ of healthy shrimp DNA as the template (lane 14). Lane $M$ contained a 100 bp size marker. The faint bands visible in lanes 2 to 4 are primer dimers 
Table 1. Sensitivity of RT-PCR and H\&E for detection of YHV at various times post infection. Haem: haemolymph; ND: not done

\begin{tabular}{|ccccccc|}
\hline $\begin{array}{l}\text { Time post } \\
\text { injection }(\mathrm{h})\end{array}$ & $\begin{array}{c}\text { No. exposed } \\
\text { shrimp tested }\end{array}$ & Weak & $\begin{array}{c}\text { RT-PCR positive } \\
\text { Light }\end{array}$ & Medium & Strong & $\begin{array}{c}\text { H\&E staining positive } \\
\text { Haem } \\
\text { Gills }\end{array}$ \\
\hline 0 & 3 & 0 & 0 & 0 & 0 & 0 \\
6 & 3 & 1 & 1 & 0 & 0 & 0 \\
12 & 3 & 0 & 1 & 1 & 1 & 0 \\
18 & 3 & 0 & 0 & 1 & 2 & 0 \\
$24-36$ & 9 & ND & ND & ND & ND & 0 \\
42 & 3 & ND & ND & ND & ND & 0 \\
48 & 3 & ND & ND & ND & 3 \\
\hline
\end{tabular}

\section{DISCUSSION}

The purpose of this work was to develop a specific and sensitive RT-PCR for the detection of YHV. If successful, the detection of YHV RNA by this process would have advantages over direct dot blot nucleic acid hybridization tests in terms of a higher sensitivity and a shorter detection time. However, the conditions have to be optimized in order to obtain the highest sensitivity and to eliminate non-specific amplification. The disadvantage is the requirement for equipment and reagents to carry out $\mathrm{PCR}$ amplification and agarose gel electrophoresis. On the other hand, there are alternatives which can eliminate the need for agarose gel electrophoresis detection of PCR products. These include possible modifications for rapid (30 min) membrane-based or microtiter plate-based visual detection by reverse hybridization using biotinylated dUTP incorporation during PCR amplification (see BoehringerMannheim catalogue). There is also a recently described experimental method for direct and rapid visual detection of hybridization which might be developed for use with normal, unlabelled PCR amplification products (Elghanian et al. 1997). These types of detection can be used to combine the sensitivity of PCR amplification and hybridization without the need for electrophoresis

The primer pair (10F and $144 \mathrm{R}$ ) appeared to be YHVRNA specific, since an RT-PCR product of expected size was amplified only when nucleic acid isolated from YHV-infected Penaeus monodon was used as a template. The nucleic acids extracted from tissues of naturally diseased shrimp with YHV and from shrimp with experimental infections of YHV also consistently gave RT-PCR products of the same size (data not shown). As expected, no amplification product was obtained when using nucleic acids extracted from the tissues of clinically healthy shrimp and from various microorganisms.

The problem with the normal histological laboratory procedures (i.e. fixing, embedding, sectioning, staining and mounting) is that they may require several days to complete and they are too slow for farmers who need rapid confirmation in order to decide on an emergency salvage harvest before remaining shrimp die. Rapid staining of gills (Flegel et al. 1997) combined with staining of haemolymph smears (Nash et al. 1995) can speed up the diagnosis to within $3 \mathrm{~h}$. However, the characteristic YHV histopathology can be seen in the gills of only moribund shrimp, so rapid staining of gills has no predictive value. The predictive value of haemolymph smears may also be low, since the laboratory tests showed that YHV histopathology could not be seen earlier than $42 \mathrm{~h}$ p.i., near the time of approaching morbidity. The gross signs of typical YHV infections (i.e. abnormally high feeding rates before the onset of mortality and light yellow coloration of the cephalothorax) do not help because they are not always seen in YHV outbreaks (Felgel et al. 1995). Thus, RT-PCR may be a way of solving these problems. It is very sensitive, specific, and capable of providing diagnostic results within a day. The technique may also prove useful for comparative studies of similar viruses (e.g. that described by Spann et al. 1995) and for screening of carrier shrimp larvae, carrier broodstock and reservoir host.s. However, the practicality and cost-effectiveness of RT-PCR for routine surveillance has not yet been established and, therefore, its diagnostic efficiency in field applications remains to be determined.

Acknowledgements. The authors thank the National Center for Genetic Engineering and Biotechnology of Thailand and the Thailand Research Fund for funds to carry out this work.

\section{LITERATURE CITED}

Boonyaratpalin S, Supamataya K, Kasornchandra J, Direkbusarakom S, Ekpanithanpong U, Chantanachookin C (1993) Non-occluded baculo-like virus, the causative agent of yellow-head disease in black tiger shrimp Penaeus monodon. Fish Pathol 28:103-109

Chantanachookhin C, Boonyaratpalin S, Kasornchandra J, Direkbusarakom S, Ekpanithanpong U, Supamataya K, Sriurairatana S. Flegel TW (1993) Histology and ultrastructure reveal a new granulosis-like virus in Penaeus monodon affected by yellow-head disease. Dis Aquat Org 17:145-1.57

Elghanian R, Storhoff JJ, Mucic RC, Letsinger RL, Mirkin CA 
(1997) Selective colorimetric detection of polynucleotides based on the distance-dependent optical properties of gold nanoparticles. Science 277:1078-1081

Flegel TW, Boonyaratpalin S, Withyachumnarnkul B (1997) Current status of research on yellow-head virus and white-spot virus in Thailand. In: Flegel TW, MacRae I (eds) Diseases in Asian aquaculture III. Fish Health Section, Asian Fisheries Society, Manila (in press)

Flegel TW, Fegan DF, Sriurairatana S (1995) Environmental control of infectious shrimp diseases in Thailand. In: Shariff $M$, Arthur JR, Subasinghe R (eds) Diseases in Asian aquaculture II. Fish Health Section, Asian Fisheries Society, Manila, p 65-79

Flegel TW, Sriurairatana S, Wongterrasupaya $C$, Boonsaeng V. Panyim S, Withyachumnarnkul B (1995) Progress in characterization and control of yellow-head virus of Penaeus monodon. In: Browdy CL, Hopkins JS (eds) Swimming through troubled water. Proceedings of the special session on shrimp farming, Aquaculture ' 95 . World Aquaculture Society, Baton Rouge, p 76-83

Lightner DV (ed) (1996) A handbook of pathology and diagnostic procedures tor diseases of penaeid shrimp. World Aquaculture Society, Baton Rouge

Limsuwan C (1991) Handbook for cultivation of black tiger prawns. Tansetaki Co Ltd, Bangkok (in Thai)

Lu Y, Tapay LM, Brock JA, Loh PC (1994) Infection of the yellow head baculo-like virus (YBV) in two species of penaeid shrimp, Penaeus stylirostris (Stimpson) and

Editorial responsibility: Otto Kinne, Oldendorf/Luhe, Germany
Penaeus vannamei (Boone). J Fish Dis 17:649-656

Lu Y, Tapay LM, Gose RB, Brock JA, Loh PC (1997) Infectivity of yellow-head virus (YHV) and the Chinese baculo-like virus (CBV) in two species of penaeid shrimp, Penaeus stylirostris (Stimpson) and $P$. vannamej (Boone). In: Flegel TW, MacRae I (eds) Diseases in Asian aquaculture III. Fish Health Section, Asian Fisheries Society, Manila (in press)

Nash GL, Akarajamorn A, Withyachumnarnkul B (1995) Histology and rapid haemocytic diagnosis of yellow-head disease in Penaeus monodon. Diseases in Asian aquaculture II. Fish Health Section, Asian Fisheries Society, Manila

Spann KM, Cowley JA, Walker PJ, Lester RJG (1998) A yellow-head-like virus from Penaeus monodon cultured in Australia. Dis Aquat Org 31:169-179

Spann KM, Vickers JE, Lester RJG (1995) Lymphoid organ virus of Penaeus monodon from Australia. Dis Aquat Org 23:127-134

Wongteerasupaya $C$, Sriurairatana $S$, Vickers JE, Anutara $A_{1}$ Boonsaeng V, Panyim S, Tassanakajon A, Withyachumnarnkul B, Flegel TW (1995a) Yellow-head virus of Penaeus monodon is an RNA virus. Dis Aquat Org 22:45-50

Wongteerasupaya C, Vickers JE, Sriurairatana S, Nash GL, Akarajamorn $A$, Boonsaeng $V$, Panyim S, Tassanakajon A, Withyachumnarnkul B, Flegel TW (1995b) A nonoccluded, systemic baculovirus that occurs in cells of ectodermal and mesodermal origin and caused high mortality in the black tiger prawn Penaeus monodon. Dis Aquat Org $21: 69-77$

Submitted: July 15, 1997; Accepted: November 12, 1997 Proofs received from author(s): December 22, 1997 